\title{
Symbiodinium spp. associated with scleractinian corals from Dongsha Atoll (Pratas), Taiwan, in the South China Sea
}

\author{
Shashank Keshavmurthy ${ }^{\text {Corresp., }}{ }^{1}$ ， Kuo-Hsun Tang ${ }^{1,2}$, Chia-Min Hsu ${ }^{1}$, Chai-Hsia Gan ${ }^{1}$, Chao-Yang Kuo ${ }^{1,3}$, \\ Keryea Soong ${ }^{4}$, Hong-Nong Chou ${ }^{5}$, Chaolun Allen Chen ${ }^{1,6,7}$ \\ 1 Biodiversity Research Center, Academia Sinica, Taipei, Taiwan \\ 2 Institute of Fisheries, National Taiwan University, Taipei, Taiwan \\ 3 ARC Centre of Excellence for Coral Reef Studies, James Cook University, Townsville, Queensland, Australia \\ 4 Department of Oceanography, Dongsha Atoll Research Station, National Sun Yat-Sen University, Kaohsuing, Taiwan \\ 5 Institute of Fisheries Science, National Taiwan University, Taipei, Taiwan \\ 6 Taiwan International Graduate Program (TIGP)-Biodiversity, Academia Sinica, Taipei, Taiwan \\ 7 Institute of Oceanography, National Taiwan University, Taipei, Taiwan \\ Corresponding Author: Shashank Keshavmurthy \\ Email address: shashank@gate.sinica.edu.tw
}

Dongsha Atoll (also known as Pratas) in Taiwan is the northernmost atoll in the South China Sea and a designated marine national park since 2007. The marine park's scope of protection covers the bio-resources of its waters in addition to uplands, so it is important to have data logging information and analyses of marine flora and fauna, including their physiology, ecology, and genetics. As part of this effort, we investigated Symbiodinium associations in scleractinian corals from Dongsha Atoll through surveys carried out at two depth ranges (shallow, 1-5 m; and deep, 10-15 m) in 2009 and during a bleaching event in 2010. Symbiodinium composition was assessed using restriction fragment length polymorphism (RFLP) of $28 \mathrm{~S}$ nuclear large subunit ribosomal DNA (nlsrDNA). Our results showed that the 796 coral samples from seven families and 20 genera collected in 2009 and 132 coral samples from seven families and 12 genera collected in 2010 were associated with Symbiodinium C, D and C+D. Occurrence of clade D in shallow water (24.5\%) was higher compared to deep (14.9\%). Due to a bleaching event in 2010 , up to $80 \%$ of coral species associated with Symbiodinium C underwent moderate to severe bleaching. Using the fine resolution technique of denaturing gradient gel electrophoresis (DGGE) of internal transcribed spacer 2 (ITS2) in 175 randomly selected coral samples, from 2009 and 2010, eight Symbiodinium C types and two Symbiodinium D types were detected. This study is the first baseline survey on Symbiodinium associations in the corals of Dongsha Atoll in the South China Sea, and it shows the dominance of Symbiodinium clade $\mathrm{C}$ in the population. 
1 Symbiodinium spp. associated with scleractinian corals from Dongsha Atoll

2 (Pratas), Taiwan, in the South China Sea

3

4 Shashank Keshavmurthy ${ }^{1 *}$, Kuo-Hsun Tang ${ }^{1,2}$, Chia-Min Hsu ${ }^{1}$, Chai-Hsia Gan ${ }^{1}$, Chao-

5 Yang Kuo ${ }^{1,3}$, Keryea Soong ${ }^{4}$, Hong-Nong $\mathrm{Chou}^{2}$, Chaolun Allen Chen ${ }^{1,5,6 *}$

6

\section{Affiliations:}

${ }^{1}$ Biodiversity Research Center, Academia Sinica, Taipei 115, Taiwan

${ }^{2}$ Institute of Fishery, National Taiwan University, Taipei 106, Taiwan

11 '3ARC Centre of Excellence for Coral Reef Studies, James Cook University, Townsville 4811, 12 Australia

13 4Dongsha Atoll Research Station, Department of Marine Science, National Sun Yat-Sen

14 University, Kaohsuing, 804, Taiwan

15 5Taiwan International Graduate Program (TIGP)-Biodiversity, Academia Sinica, Taipei, 115

16 Taiwan

17 Institute Oceanography, National Taiwan University, Taipei 106, Taiwan

\section{Corresponding authors:}

Dr. Allen Chen,

Biodiversity Research Center, Academia Sinica, Nangang, Taipei 115, Taiwan.

Tel: 8862 27899549; Fax: 886-2-27858059; E-mail: cac@gate.sinica.edu.tw

Dr. Shashank Keshavmurthy

Biodiversity Research Center, Academia Sinica, Nangang, Taipei 115, Taiwan.

Tel: 8862 27899549; Fax: 886-2-27858059; E-mail: coralresearchtaiwan@gmail.com 
32 Abstract

33 Dongsha Atoll (also known as Pratas) in Taiwan is the northernmost atoll in the

34 South China Sea and a designated marine national park since 2007. The marine park's

35 scope of protection covers the bio-resources of its waters in addition to uplands, so it is

36 important to have data logging information and analyses of marine flora and fauna,

37 including their physiology, ecology, and genetics. As part of this effort, we investigated

38 Symbiodinium associations in scleractinian corals from Dongsha Atoll through surveys

39 carried out at two depth ranges (shallow, 1-5 m; and deep, 10-15 m) in 2009 and during a

40 bleaching event in 2010. Symbiodinium composition was assessed using restriction

41 fragment length polymorphism (RFLP) of 28S nuclear large subunit ribosomal DNA

42 (nlsrDNA). Our results showed that the 796 coral samples from seven families and 20

43 genera collected in 2009 and 132 coral samples from seven families and 12 genera

44 collected in 2010 were associated with Symbiodinium C, D and C+D. Occurrence of

45 clade D in shallow water $(24.5 \%)$ was higher compared to deep $(14.9 \%)$. Due to a

46 bleaching event in 2010, up to $80 \%$ of coral species associated with Symbiodinium C

47 underwent moderate to severe bleaching. Using the fine resolution technique of

48 denaturing gradient gel electrophoresis (DGGE) of internal transcribed spacer 2 (ITS2) in

49175 randomly selected coral samples, from 2009 and 2010, eight Symbiodinium C types

50 and two Symbiodinium D types were detected. This study is the first baseline survey on

51 Symbiodinium associations in the corals of Dongsha Atoll in the South China Sea, and it

52 shows the dominance of Symbiodinium clade $\mathrm{C}$ in the population. 


\section{Introduction}

55 Coral reefs provide habitat for numerous marine organisms and are considered

56 among the richest ecosystems on earth. In addition to their ecological values, they are

57 also economically important as they contribute toward food, tourism, coastal protection,

58 aesthetics, and cultural significance to people in coastal areas (Moberg and Folke 1999;

59 Hoegh-Guldberg 2004; Wilkinson 2004) and act as ecosystem engineers (Jones et al.

60 1994; Coleman and Williams 2002). As a result of climate change and anthropogenic

61 disturbances, corals and coral reefs in the recent decades (30-40 years) have suffered an

62 unprecedented decline in terms of species abundance and community degradation

63 (Hoegh-Guldberg 1999; Coles and Brown 2003; Hughes et al. 2003; Bellwood et al. 64 2004).

65 Increasing seawater temperature is considered one of the main causes of this 66 decline (Hoegh-Guldberg et al. 2007). Generally, corals undergo a phenomenon known

67 as bleaching when confronted with $1.0-2.0^{\circ} \mathrm{C}$ above the mean summer average seawater 68 temperatures. Bleaching is a result of the breakdown of symbiosis between the coral 69 host and single celled algae Symbiodinium, either due to release of Symbiodinium cells 70 by the host or escape of the cells from the host (see Weis 2008). While a majority of 71 corals undergo bleaching, some coral species can resist thermal stress or changes in 72 environmental conditions. This is due either to the ability of the coral host to withstand 73 stress or by associating with a more thermally tolerant type of Symbiodinium, or to a 74 combination of the two (Berkelmans and van Oppen 2006; Bhagooli et al. 2008; Baird 75 et al. 2009). 
76 Based on various genetic markers (Rowan and Powers 1991a; Rowan and Powers

77 1991b; LaJeunesse 2001; van Oppen et al. 2001; Pochon et al. 2001; Fabricius et al.

78 2004; Coffroth and Santos 2005; Pochon et al. 2006; Stat et al. 2009), Symbiodinium

79 are genetically diverse and has been classified into clades, types and ectomorphs.

80 Different host-symbiont assemblages can respond differently to diverse conditions,

81 such as temperature, irradiance, and sedimentation disturbance. Most Symbiodinium

82 clades/types are associated with specific host genera or species (LaJeunesse et al.

83 2004a). In many cases, Symbiodinium clades/types associate with only one or a few host

84 species. However, studies also have shown that one of the two partners is more flexible

85 (Baker 2003a) and occupies defined ecological niches and roles within and across coral

86 hosts (LaJeunesse et al. 2010b; Pochon and Gates 2010; Weber and Medina 2012)

87 based on their physiological responses to various environmental stresses (Iglesias-Prieto

88 et al. 2004; Baker 2003a, 2003b; Jones et al. 2008; Little et al. 2004; Rowan 2004;

89 Sampayo et al. 2008; Warner et al. 2006).

90 Symbiodinium-related stress-resistant mechanisms could be a result of strict

91 association with a stress resistant clade/type of Symbiodinium or, in case of coral host

92 with multiple Symbiodinium association, the result of shuffling between stress sensitive

93 and stress resistant Symbiodinium clades/types. The capacity to shuffle Symbiodinium

94 clades/types may be key for their acclimatization and/or adaptation (Baker and

95 Romanski 2007; Mieog et al. 2007). The general trend is for thermal-tolerant

96 clades/types to supersede thermal-sensitive clades/types under temperature stress (Jones

97 et al. 2008; Jones and Berkelmans 2010). 
As coral and coral reefs face more frequent and intense bleaching events due to

99 climate change and anthropogenic stressors, it is necessary to document the coral-

100 Symbiodinium associations from locations which have been ignored or those that are

101 remote. A recent study from western Australia have shown presence of some unique

102 Symbiodinium types as well as added to the information on coral-Symbiodinium

103 associations and Symbiodinium diversity (Silverstein et al. 2011). Such studies will help

104 us to understand the current status and predict future response of the corals in new and

105 remote locations.

106 Dongsha Atoll in the South China Sea is one such remote location. Although many

107 studies have been conducted on coral-Symbiodinium associations in the South China

108 Sea, no such efforts have been realized in Dongsha Atoll. The Dongsha Atoll Marine

109 National Park was established in 2007 in order to implement legal jurisdiction for

110 conservation efforts. Several studies have been conducted on its reef-building corals

111 despite its remote location. For example, Ma (1937) studied growth rates in different

112 coral species. Coral biodiversity (17 genera and 45 species) was first described by Yang

113 et al. (1975), followed by Fang et al. (1990), who reported 28 genera and 63 species.

114 Later, Dai et al. (1995) recorded 34 genera and 101 species of scleractinian corals, eight

115 genera and 33 species of octocorals, and one genus and three species of hydrocorallina.

116 Recently, and especially after 1998, interest has arisen on the effects of mass coral

117 bleaching of the coral reef community of Dongsha Atoll. After the exceptionally high

118 1997-98 summer temperatures during an El Niño-Southern Oscillation (ENSO)

119 bleaching event, different studies reported a decrease in its coral cover and biodiversity

120 (Fang 1998; Li and Fang 2002; Soong et al. 2002). Moreover, Li et al. (2000) showed a 
121 decline in coral species number due to the extensive use of poisons and explosives from

122 illegal fishing. Before 1998, Porites and Acropora were the most abundant and

123 widespread genera in Dongsha (Fang et al. 1990; Dai et al. 1995). Although Porites has

124 remained a dominant genus from 1998 to the present, it has shared its dominance with

125 other species belonging to the Merulinidae and Fungiidae (Dai 2013).

126 Although the species diversity of scleractinian corals at Dongsha has been 127 investigated extensively (Fang et al. 1990; Li et al. 2000; Soong et al. 2002; Dai et al. 128 1995; Dai 2005, 2006, 2008, 2013), no studies have been carried out on the coral129 Symbiodinium associations. Dongsha Atoll is characterized by well-developed tropical 130 atoll reefs with 281 known scleractinian coral species (Dai 2013). Direct anthropogenic

131 disturbances on the atoll are minimal (about 200 military personnel and park rangers) 132 since Dongsha is a military-exclusive area and a designated marine national park.

133 However, there is occasional human disturbance by fishermen from nearby coastal 134 nations, including China, Philippines, and Vietnam. Hence, the aim of this study was to 135 conduct a baseline survey on Symbiodinium associations in the corals of Dongsha Atoll 136 and document the Symbiodinium diversity in shallow and deep waters at different sites

137 in the lagoon of the Atoll in 2009 and 2010. In this paper, we report the results from the 138 preliminary survey carried out in the lagoon of Dongsha Atoll on coral-Symbiodinium 139 associations. 


\section{Materials and methods}

143 Description of the study site and sample collection

144 Dongsha Atoll $\left(20^{\circ} 35^{\prime}-47^{\prime} \mathrm{N}\right.$ and $\left.116^{\circ} 41^{\prime}-55^{\prime} \mathrm{E}\right)$, also known as Pratas Island

145 (Fig. 1), is located in the northern South China Sea, $850 \mathrm{~km}$ southwest of Taiwan.

146 Dongsha is a circular atoll about $25 \mathrm{~km}$ in diameter and its central lagoon covers more

147 than $600 \mathrm{~km}^{2}$. Depths in the lagoon range $10-15 \mathrm{~m}$ with a maximum depth of $23.7 \mathrm{~m}$

148 (Dai, 2013). Composed of coral debris, Dongsha Island is small (2,860 m long $865 \mathrm{~m}$

149 wide), $2 \mathrm{~m}$ above sea level at most, covers a total surface area of $1.74 \mathrm{~km}^{2}$, and is

150 located in the western part of the atoll. The circular reef flat around the lagoon spreads

151 over $46 \mathrm{~km}$ and its maximum width reaches $2 \mathrm{~km}$.

152 Coral samples were collected in June and September 2009 and September 2010 in

153 the Dongsha Atoll Lagoon (DAL) (Fig. 1). There was a bleaching episode during

154 summer of 2010 due to elevated seawater temperatures. The corals underwent bleaching 155 mostly in the shallow waters of DAL. Bleached and non-bleached corals were 156 determined by visual survey of color variation between healthy and bleached corals.

157 Sampling was limited to the lagoon due to military-restricted access to the reef crest and 158 outside the atoll. A total of 928 scleractinian coral samples including seven families 159 with 20 and 12 genera in 2009 and 2010 respectively, were collected at two depths: 1-5 $160 \mathrm{~m}$ (shallow) and 10-15 m (deep). Samples in 2009 and 2010 were collected from nine 161 and four sites, respectively. Samples $(\sim 5-10 \mathrm{~cm})$ form coral colonies were randomly

162 collected by hammer and chisel. All the samples were preserved in $70 \%$ ethanol (v/v) 163 and kept at $4{ }^{\circ} \mathrm{C}$ until processing. Scleractinian corals were identified to species when 164 possible. Scleractinian taxonomy followed Veron and Stafford-Smith (2000), Dai and 
165 Horng (2009a, b), and Huang et al. (2014). In situ seawater temperatures at every site

166 and at both depths were recorded with temperature loggers (HOBO, Pendant ${ }^{\mathrm{TM}}$, Onset

167 Computer Corporation, Massachusetts, USA) at 30 min intervals (the periods of record

168 were June 17 to September 15, 2009, and May 28 to September 6, 2010).

169 DNA extraction

170 Total genomic DNA (coral host + Symbiodinium) was extracted by the salting-out 171 method (Ferrara et al. 2006). Coral tissue was lysed overnight in a $2 \mathrm{~mL}$ Eppendorf tube 172 with $200 \mu \mathrm{L}$ of lysis buffer [0.25 M Tris, $0.05 \mathrm{M}$ EDTA at $\mathrm{pH} 8.0,2 \%$ sodium 173 dodecylsulfate (SDS), and $0.1 \mathrm{M} \mathrm{NaCl}]$ and $10 \underline{\mu L}$ of $10 \mathrm{mg} \mathrm{mL}^{-1}$ proteinase $\mathrm{E}$ at $55^{\circ} \mathrm{C}$ 174 in a water bath. $\mathrm{NaCl}(210 \mu \mathrm{L}$ at $7 \mathrm{M})$ was added to the lysed tissue in the tube and the 175 sample mixed carefully by inverting the tube. The solution was then transferred to a 2 $176 \mathrm{~mL}$ collection tube containing a DNA spin column (Viogene, USA) and centrifuged at $1778000 \mathrm{rpm}$ for $1 \mathrm{~min}$. The lysate was washed twice with $500 \mu \mathrm{L}$ of ethanol $(70 \%)$ by 178 centrifuging at $8000 \mathrm{rpm}$ for $1 \mathrm{~min}$ at each step, with an additional centrifugation step at

$1798000 \mathrm{rpm}$ for $3 \mathrm{~min}$ to dry the spin column. The column was dried further at $37^{\circ} \mathrm{C}$ for $18015 \mathrm{~min}$ and the DNA then eluted by adding $150 \mu \mathrm{L}$ of distilled water, with a final 181 centrifugation at $14,000 \mathrm{~g}$ for $3 \mathrm{~min}$. The quality of genomic DNA was checked using a $1821 \%$ agarose gel and the concentration of eluted DNA was examined using NanoDrop 183 and then stored at $-20^{\circ} \mathrm{C}$ for further analysis.

Molecular identification of Symbiodinium clades (28S RFLP) and types (ITS2 DGGE)

186 A total of 928 samples (20 genera in 2009 and 12 genera in 2010) were used to 187 analyze Symbiodinium clade composition using RFLP method modified from Chen et 
188 al. (2005a, b). The 5' end of nuclear large subunit ribosomal DNA (nlsrDNA) was

189 amplified using a Symbiodinium-specific primer set, 28Szoox-D1/D2F (5'-CCT CAG

190 TAA TGG CGA ATG AAC A-3') and 28Szoox-D1/D2R (5'-CCT TGG TCC GTG TTT

191 CAA GA-3') (Loh et al. 2001). A $25 \mu \mathrm{l}$ PCR reaction consisting of $3 \mu \mathrm{l}$ DNA (10 ng $\mu \mathrm{l}^{-}$

$\left.192{ }^{1}\right), 2 \mu \mathrm{l}$ dNTPs $(0.8 \mathrm{mM}), 2 \mu \mathrm{l}$ forward primer $(0.16 \mu \mathrm{M}), 2 \mu \mathrm{l}$ reverse primer $(0.16 \mu \mathrm{M})$,

$1933 \mu \mathrm{l}$ PCR Buffer (1.2X), 0.5 unit Taq polymerase (Protech, Taiwan), and $12.5 \mu \mathrm{l}$

194 distilled water was run on a Px2 thermal cycler (Thermo Scientific, USA). The PCR

195 cycling profile consisted of initial denaturation at $95{ }^{\circ} \mathrm{C}$ for 1 min followed by 5 cycles

196 of $94{ }^{\circ} \mathrm{C}$ for $30 \mathrm{~s}, 30$ cycles of annealing at $55{ }^{\circ} \mathrm{C}$ for $1 \mathrm{~min}$ and decreasing $1{ }^{\circ} \mathrm{C}$ to a

197 final annealing temperatures of $50{ }^{\circ} \mathrm{C}$ and $2 \mathrm{~min}$ at $72{ }^{\circ} \mathrm{C}$. The final extension was at 72

$198{ }^{\circ} \mathrm{C}$ for $10 \mathrm{~min}$. The PCR product was digested with Rsa I (BioLabs, USA) solution at 37

$199{ }^{\circ} \mathrm{C}$ overnight and then run on $3 \%$ agarose gel ( $2 \%$ low melting agarose with $1 \%$

200 agarose) at $50 \mathrm{~V}$ for $3 \mathrm{~h}$. Bands were stained using ethidium bromide (EtBr) and 201 visualized under ultraviolet radiation.

202 For ITS2 Symbiodinium type composition, 168 samples were randomly picked 203 from 17 genera in 2009 and 11 genera in 2010. The ribosomal internal transcribed 204 spacer 2 (ITS2) region of Symbiodinium was amplified using the primers ITSintfor2, 5'205 GAA TTG CAG AAC TCC GTG-3', and ITS2clamp, 5'-CGC CCG CCG CGC CCC 206 GCG CCC GTC CCG CGG GAT CCA TAT GCT TAA GTT CAGCGG GT-3’

207 (LaJeunesse and Trench 2000). Each $50 \mu$ polymerase chain reaction (PCR) comprised $20850 \mathrm{ng}$ of genomic DNA, PCR buffer, $2.5 \mathrm{mM} \mathrm{MgCl}_{2}, 0.4 \mathrm{mM}$ dNTPs, $0.4 \mu \mathrm{M}$ of each

209 primer, and 2 units of Taq polymerase (Invitrogen, USA). The PCR was run on a Px2 210 thermal cycler (Thermo Scientific, MA, USA) with a touch-down PCR (LaJeunesse 
211 2002) to ensure specificity. An initial denaturation period at $92{ }^{\circ} \mathrm{C}$ for 3 min was

212 followed by 20 cycles of $30 \mathrm{~s}$ at $92{ }^{\circ} \mathrm{C}$, annealing from $62{ }^{\circ} \mathrm{C}$ to a final annealing

213 temperature of $52{ }^{\circ} \mathrm{C}$ with decrements of $0.5^{\circ} \mathrm{C}$, and $30 \mathrm{~s}$ at $72{ }^{\circ} \mathrm{C}$. Once the annealing

214 temperature reached $52{ }^{\circ} \mathrm{C}$, a further 20 cycles were performed at that annealing

215 temperature, with a final extension period of 10 min at $72{ }^{\circ} \mathrm{C}$. Each PCR product along

216 with Symbiodinium type markers (known ITS2 sequences confirmed by comparing with

217 NCBI GenBank database) was loaded onto an acrylamide denaturing gradient gel (45-

218 80\%) and electrophoresed at $115 \mathrm{~V}$ for $15 \mathrm{~h}$ using a CBS Scientific system (Del Mar,

219 CA, USA). Gels were stained with SYBR Green (Molecular Probes, Eugene, OR, USA)

220 for $15 \mathrm{~min}$ and photographed for further analysis. Band patterns were confirmed by

221 sequencing the bands cut from the DGGE gel.

222 Statistical analysis

223 Shallow and deep-water temperature comparisons were analyzed by paired $t$-tests and average

224 daily seawater temperature values presented as means \pm standard deviation (SD). The frequency

225 of daily maximum temperature fluctuation at each location and depth was calculated followed by

226 difference in temperature between shallow and deep waters. Finally, the percentage of daily

227 average seawater temperature of over $30{ }^{\circ} \mathrm{C}$ during the monitoring period was calculated. The

228 Symbiodinium clade values in 2009 and 2010 were converted to percentage within and between

229 genera and within and between two depths. The proportion of Symbiodinium clades in coral

230 genera in 2009 and 2010 and between shallow and deep waters was analyzed using a chi-square

231 test. All graphs were drawn using Aabel (Ver. 3.0, Gigawiz Ltd. Co., USA) or Datagraph (Visual

232 Data Tools, USA) software for the Macintosh platform. 


\section{Results}

237 Seawater temperature

238 Seawater temperature was recorded (30 min intervals) from June 17 to September 15, 2009, and

239 May 28 to September 6, 2010 (Fig. 2A and B, Supplementary data files S1-S3). During the 2009

240 period, daily average temperatures at shallow waters $\left(29.55 \pm 0.23{ }^{\circ} \mathrm{C}\right)$ were higher than at deep

241 waters $\left(28.82 \pm 0.19^{\circ} \mathrm{C}\right.$; Fig. $2 \mathrm{~A}$; Table 1 ; paired $t$-test, $\left.\mathrm{p}<0.001\right)$. Similarly, in 2010 ,

242 temperatures at shallow waters $\left(29.94 \pm 0.29^{\circ} \mathrm{C}\right)$ were higher than at deep waters $(29.72 \pm 0.32$

$243{ }^{\circ} \mathrm{C}$; Fig. 2A; Table 1; paired $t$-test, $\left.\mathrm{p}<0.001\right)$. Overall, $\Delta \mathrm{T}$ was $0.62 \pm 0.3{ }^{\circ} \mathrm{C}$ in 2009 and $0.22 \pm$

$2440.14{ }^{\circ} \mathrm{C}$ in 2010 . Daily temperature differences between shallow and deep waters in 2009 were

$2450.5-1.0{ }^{\circ} \mathrm{C}$ and $0-0.5^{\circ} \mathrm{C}$ in 2010 . In 2009 , during the period monitored, $36 \%$ of the temperatures

246 (number of days) recorded at the shallow waters exceeded $30.0^{\circ} \mathrm{C}$, whereas only $13 \%$ of the

247 temperatures (number of days) recorded at the deep waters reached this value. In 2010, for

248 shallow and deep waters, $61 \%$ and $55 \%$ of the temperatures (number of days) recorded exceeded

$24930.0^{\circ} \mathrm{C}$. This was also confirmed by the heat map of seawater temperatures measured at reef

250 base and reef top during June- September and May-September in 2009 and 2010 (Fig. 2 B)

251 In this study, samples were collected from nine locations in the DAL. Since the sampling was

252 random and uneven within and between locations and between two sampling times (2009 and

253 2010), we present results from 2009 and 2010 by combining the data for locations and depths,

254 rather than discussing the results from individual locations and depths. Hence, we present the

255 overall picture of coral-Symbiodinium associations in DAL. Data of Symbiodinium clades in

256 coral genera at different locations is provided as supplementary data file S4.

258 Symbiodinium clade composition in 2009 
A total of 796 samples from 20 genera and seven families were collected in 2009

260 (Fig. 3 and 4). RFLP band patterns revealed the presence of Symbiodinium clades C, D

261 and $\mathrm{C}+\mathrm{D}$.

262 Symbiodinium Clade C occurred in all 20 genera at shallow and deep waters in 263 2009. Leptastrea (100\%), Fungia (100\%), and Porites (100\%) were found to harbor 264 only Symbiodinium clade C at shallow and deep waters. Cyphastrea (100\%), 265 Hydnophora (100\%), Montipora (100\%), and Psammocora (100\%) were associated 266 only with Symbiodinium clade C at deep waters. At shallow waters, the proportion of 267 Symbiodinium clades was 64.18\% (clade C), 24.5\% (clade D), and 11.34\% (clades $268 \mathrm{C}+\mathrm{D}$ ). And, at deep waters, the proportion of Symbiodinium clades was $78.6 \%$ (clade 269 C), $14.9 \%$ (clade D), and 6.53\% (clades C+D). The clade D proportion in comparison 270 to clade $\mathrm{C}$ was significantly different at shallow and deep waters (chi-square test, $\mathrm{p}=$ 0.007). The clade D proportion was high at shallow waters $(24.5 \%)$ compared to deep waters $(14.9 \%)$. At both depths, most corals were associated with $>50 \%$ of Symbiodinium clade C, the exceptions being Oxypora (33\% in shallow and $44 \%$ in 274 deep), Hydnophora (22\% in shallow), Echinopora (9\% in shallow and $24 \%$ in deep), 275 Favites (33\% in shallow), Coelastrea (37\% in shallow), Astrea (25\% in shallow), 276 Pectinia (38\% in shallow) and Goniopora (43\% in shallow), which were associated > $27750 \%$ of the time with clades $\mathrm{D}$ or $\mathrm{C}+\mathrm{D}$. However, care should be taken when 278 interpreting the results from this data since the sample number was less than ten for 279 most of these genera.

280 Compared to other genera, Clade D proportions in Turbinaria and Coelastrea were 281 significantly different when comparing shallow to deep (chi-square test, $\mathrm{p}<0.05$ ). The 
282 clade D proportion of Turbinaria at shallow waters (39.5\%) was higher than at deep

283 waters (10.8\%), and in Coelastrea was $46.7 \%$ at shallow waters and $15 \%$ at deep

284 waters.

285

286 Symbiodinium clade composition in corals during the 2010 bleaching episode

287 A total of 132 samples from 12 genera and seven families were sampled in 2010

288 from shallow and deep waters (Fig. 3 and 4). Symbiodinium clade D showed significant

289 differences (chi-square test, $\mathrm{p}<0.001$ ) between bleached and non-bleached corals.

290 Clade D proportions were extremely high in non-bleached corals $(62.8 \%)$ compared to

291 bleached corals (10.9\%). Bleached corals were dominated by Symbiodinium clade C at

292 each location. Astreopora, Psammocora, Fungia, Cyphastrea, Porites, and Oxypora, all

293 associated with clade C, experienced bleaching in Dongsha Lagoon in the summer of

294 2010, and Pavona, Coelastrea and Echinopora still experienced bleaching even though

295 they were associated with clades D or C+D.

296

297 Symbiodinium type composition in corals in 2009 and 2010

298 There was no particular trend in the Symbiodinium type composition between the 299 two sampling years due to random sampling of the coral colonies (Table 2). However,

300 Symbiodinium composition was dominated by different types of Symbiodinium C. ITS2

301 DGGE analysis of DNA samples revealed the presence of eight Symbiodinium types

302 (C1, C1b, C3, C15, C21a, C27, C30 and C40 Table 2). C15 was mainly associated with

303 Montipora and Porites. The composition of Symbiodinium type D consisted of only two

304 types; Symbiodinium glynii (D1) and Symbiodinium trenchii (D1a), either separately or 
305 in combination, depending on the coral host genus. The two species of Symbiodinium D 306 are separated based on a one base-pair difference on a DGGE gel. Because of this fine

307 difference, we ran the gels with appropriate markers for S. glynii and S. trenchii and also 308 sequenced the cut bands from the ITS2 DGGE gels to reveal the presence of S. glynii in 309 several genera of corals sampled from DAL (Fig S1).

310 Out of 17 genera analyzed in 2009, the genera Montipora, Acropora, Pavona, 311 Oxypora, Echinopora Favites, Astrea, Coelastrea, Gonipora, Hydnopora and

312 Pachyseries were associated with S. glynii and/or S. trenchii (Table 2). Out of 12 genera

313 analyzed in 2010, the genera Pavona, Turbinaria, Oxypora, Echinopora, Astrea and

314 Gonipora were associated with S. glynii and/or S. trenchii (Table 2). 


\section{Discussion}

317 This is the first study to investigate Symbiodinium association in the corals of

318 Dongsha Atoll Lagoon (DAL). The main results of this study are that (1) Symbiodinium

319 composition in DAL consists of two clades, C and D; (2) eight Symbiodinium C types

320 were detected compared to only two Symbiodinium D types; and (3) up to $80 \%$ of coral

321 species associated with Symbiodinium C underwent moderate to severe bleaching in the

322 year 2010. Since we have utilized both RFLP and DGGE for analysis, to avoid

323 confusion, throughout the discussion, clades and types will not be used and instead we

324 will just use either Symbiodinium C or Symbiodinium D. We also use species name for

325 those Symbiodinium types that have been designated formally.

326 Out of 928 samples collected from 20 (in 2009) and 12 (in 2010) genera of

327 scleractinian corals, 598 hosted Symbiodinium C, suggesting its dominance in the South

328 China Sea (see Table 3). The association of corals with Symbiodinium C, in addition to

329 physiological factors, could also be due to seawater temperatures being generally below

330 the bleaching threshold in Dongsha (Fig. 2, Table 1).

331

332 Symbiodinium association in corals in 2009

333 In 2009, despite Symbiodinium C being dominant, it is interesting to highlight the

334 differences seen in Symbiodinium D. There was higher proportion $(24.5 \%)$ in shallow

335 waters compared to deep waters (14.9\%). Moreover, the occurrence of S. glynii and S.

336 trenchii was higher in corals sampled from the shallow waters. The frequency of

337 temperature fluctuations $>1{ }^{\circ} \mathrm{C}$ at shallow waters was higher than at deep waters, which 
338 might be one of the reasons for the higher proportions of Symbiodinium D at shallow

339 than at deep waters.

340 In the present study, Astreopora, Pavona, Montipora, Psammocora, Porites,

341 Fungia and Leptastrea showed stable associations with Symbiodinium C at shallow and

342 deep waters in DAL, suggesting that either host might be physiologically adjusted to

343 temperature stress or their associated Symbiodinium $\mathrm{C}$ might have greater

344 photosynthetic stability under thermal stress (Berkelmans et al. 2004; Thornhill et al.

345 2005; van Oppen et al. 2005). Turbinaria, Oxypora, Hydnophora, Coelastrea, and

346 Favites, which were dominated by Symbiodinium D at shallow compared to deep

347 waters, suggest flexibility in symbiont association in these corals to warmer waters via

348 Symbiodinium D. The coral Echinopora had a stable and dominant association with

349 Symbiodinium D at shallow and deep waters. In the present study, the proportion of

350 Symbiodinium D showed a significant difference only in some locations, which might

351 be due to difference distribution of coral host associated with Symbiodinium D.

352

353 Symbiodinium association in corals in 2010 during a bleaching event

354 In 2010, scleractinian corals at Dongsha suffered from high seawater temperature

355 stress caused by a La Niña event. Astreopora, Cyphastrea, Fungia, Psammacora

356 associated with clade $\mathrm{C}$ including the genus Porites, which is generally considered as

357 stress resistant (associated with Symbiodinium C15) experienced bleaching. Moreover,

358 coral genera Pavona, Coelastrea, Echinopora, which were associated with clade C or

$359 \mathrm{C}+\mathrm{D}$, also experienced bleaching. Bleaching was seen in $84 \%$ of corals associated with

360 clade C compared to only $10.87 \%$ of corals associated with clade D. Bleaching in those 
361 corals associated with clade D could be due to seawater temperature above threshold

362 limits during the summer of 2010. In a previous study, the critical coral bleaching

363 temperature threshold at Dongsha was determined to be $29.6{ }^{\circ} \mathrm{C}$ (Dai, 2008). During

364 May 28 to September 6,2010 , average temperatures at shallow waters $\left(29.9^{\circ} \mathrm{C}\right)$ and

365 deep waters $\left(29.7^{\circ} \mathrm{C}\right)$ within DAL exceeded the critical value and may have induced

366 coral bleaching (Fig. 2, Table 1). Consistent above $30^{\circ} \mathrm{C}$ seawater temperature for more

367 than a week, both in shallow and deep waters, could have resulted in extensive

368 bleaching in corals in 2010 (Fig. 2, Table 1). As a result of random and uneven

369 sampling, it is not possible to analyze the correlation between Symbiodinium clades and

370 seawater temperature results. We suggest that future studies in DAL should focus on

371 obtaining samples from tagged coral colonies in different seasons and depths to

372 understand the dynamics of coral-Symbiodinium associations.

373

374 Symbiodinium type composition in corals in 2009 and 2010

375 From ITS2 DGGE analysis, DAL corals were found to be associated with eight

376 Symbiodinium C (Symbiodinium goreaui (C1), C1b, C3, C15, C21a, C27, C30 and C40)

377 and this number is greater than in the corals at Kenting, southern Taiwan

378 (Keshavmurthy et al. 2014). Conversely, only two Symbiodinium D types were

379 observed: Symbiodinium glynii (D1) and Symbiodinium trenchii (D1a). The presence of

380 Symbiodinium D in corals sampled in 2010 was more obvious, and we believe this

381 might have been due to the influence of seawater temperature (Fig. 2, Table 1). Our

382 results also showed that S. glynii was dominant in many coral genera, both in 2009 (12

383 genera out of 20) and 2010 (7 genera out of 12), indicating that S. glynii may not be 
384 specific to any particular host species (LaJeunesse 2002; Baker 2003). This is the first

385 work to show the presence of S. glynii in such a large number of coral genera and hence,

386 we believe that $S$. glynii may not be as specific or rare, as previously thought (see

387 LaJeunesse et al. 2010a).

388

389 Conclusions

390 The present study has shown that Symbiodinium C is dominant at Dongsha Atoll in the

391 South China Sea corals and that natural stressors, such as elevated seawater temperatures, can

392 influence Symbiodinium associations in Dongsha Atoll corals. The baseline information provided

393 on the composition of Symbiodinium in corals from Dongsha Atoll through the present work will

394 help carrying out comprehensive and detailed studies on the diversity of Symbiodinium in corals

395 over time. By analyzing data from normal and coral-bleaching years, we have shown that the

396 composition of Symbiodinium in some corals is different between years in remote and

397 undisturbed locations such as Dongsha Atoll. Such studies are important for understanding the

398 future responses of corals to climate change in remote atolls. With increasing threats to coral

399 health, mainly from temperature-induced bleaching events as seen in the Great Barrier Reef in

400 2016, studies documenting the Symbiodinium associations in corals of Donghsa Atoll will help to

401 educate and inform park managers of Dongsha Atoll Marine National Park managers about

402 appropriate management and conservation measures. The focus on the status of coral reefs in the

403 South China Sea, including Dongsha Atolls, has gained attention in the past couple of years,

404 particularly due to the recent destruction via land-filling of several reefs several atolls in the

405 South China Sea. Although offshore atoll reefs in the South China Sea are found to be in better

406 condition than near-shore reefs (Hughes et al. 2013), they can still undergo bleaching and 
407 mortality as a result of climate change (Graham et al. 2006) and other stressors (Hughes et al.

408 2013). Trans boundary cooperation in the South China Sea region has become important for the

409 maintenance and conservation of the various atolls and islands in the South China Sea

410 (McManus et al. 2010). As part of the conservation program in Dongsha Atoll, it is necessary to

411 combine the influence of natural disturbances and the effects of anthropogenic stressors, such as

412 fishing activities, in order to understand the alterations of the present and their influences on

413 future coral communities.

414

\section{Acknowledgements}

416 We thank the staff of the Dongsha Atoll Marine National Park, Dongsha Atoll Research Station,

417 Ministry of Science and Technology (MOST), Taiwan and support from members of the Coral

418 Reef Ecology Lab, Biodiversity Research Center, Academia Sinica (BRCAS). 
420

421

422

423

424

425

426

427

428

429

430

431

432

434

435

436

437

438

439

440

441

442

\section{References}

Baird AH, Bhagooli R, Ralph P, Takahashi S. 2009. Coral bleaching: the role of the host. Trends Ecology and Evolution 24: 16-20.

Baker AC. 2003a. Flexibility and specificity in coral-algal symbiosis: diversity, ecology, and biogeography of Symbiodinium. Annual Review of Ecology and Systematics 34: 661-689.

Baker AC. 2003b. Symbiont diversity on coral reefs and its relationship to bleaching resistance and resilience. In: Rosenberg E, Loya Y, eds. Coral health and disease. Berlin: Springer, 177-191. .

Baker AC, Romanski AM. 2007. Multiple symbiotic partnership are common in scleractinian corals, but not in octocorals: Comment on Goulet (2006). Marine Ecology Progress Series 335: 237-242.

Bellwood DR, Hughes TP, Folke C, Nÿstrom M. 2004. Confronting the coral reef crisis. Nature, 429: 827-833.

Berkelmans R, De'ath G, Kininmonth S, Skirving WJ. 2004. A comparison of the 1998 and 2002 coral bleaching events on the Great Barrier Reef: spatial correlation, patterns and predictions. Coral Reefs, 23: 74-83.

Berkelmans R, van Oppen MJH. 2006. The role of zooxanthellae in the thermal tolerance of corals: a 'nugget of hope' for coral reefs in an era of climate change. Proceedings of the Royal Society B-Biological Sciences 273: 2305-2312.

Bhagooli R, Baird AH, Ralph PJ. 2008. Does the coral host protect its algal symbionts from heat and light stresses? Proceedings of the eleventh International Coral Reef Symposium 5: 113-117. 
444 Chen CA, Yang YW, Wei NV, Tsai WS, Fang LS. 2005a. Symbiont diversity in 445 scleractinian corals from tropical reeds and subtropical non-reed communities in $446 \quad$ Taiwan. Coral Reefs 23: 11-22.

447 Chen CA, Wang JT, Fang LS, Yang YW. 2005b. Fluctuating algal symbiont 448 communities in Acropora palifera (Cnidaria; Scleractinia) from Taiwan. Marine $449 \quad$ Ecology Progress Series 295: 113-121.

450 Coffroth MA, Santos SR. 2005. Genetic diversity of symbiotic dinoflagellates in the 451 genus Symbiodinium. Protist 156: 19-34.

452 Coles SL, Brown BE. 2003. Coral bleaching- capacity for acclimatization and 453 adaptation. Advances in Marine Biology 46: 183-223.

454 Coleman FC, Williams SL. 2002. Overexploiting marine ecosystem engineers: potential 455 consequences for biodiversity. Trends Ecology and Evolution 17: 40-44.

456 Dai CF, Fan TY, Wu CS. 1995. Coral fauna of Tungsha Tao (Pratas Island). Acta 457 Oceanographica Taiwanica 34: 1-16.

458 Dai CF. 2005. The corals reefs ecological resources of sea area of Dongsha are 459 investigated and monitored. Construction and Planning Administration Ministry of 460 Interior request report Chapter 4: 4:1-31 (in Chinese with English abstract).

461 Dai CF. 2006. The corals reefs ecological resources of sea area of Dongsha are 462 investigated and monitored. Construction and Planning Administration Ministry of 463 Interior request report Chapter 4: 67-137 (in Chinese with English abstract). 
464 Dai CF. 2008. The corals reefs ecological resources of sea area of Dongsha are 465 investigated and monitored. Construction and Planning Administration Ministry of 466 Interior request report Chapter 4: 51-108 (in Chinese with English abstract).

467 Dai CF, Hung S. 2009a. Scleractinia of Taiwan I. The Complex Group. National 468 Taiwan University, 172 p., Taipei.

469 Dai CF, Hung S. 2009b. Scleractinia of Taiwan II.The Robust Group. National Taiwan $470 \quad$ University, 162 p., Taipei.

Dai CF, Qin XY, Zheng AY. 2013. Coral fauna of Dongsha Atoll in the South China Sea (In Chinese). National Marine Park Headquarters, Kaohsuing, Taiwan. 344 pp.

Dong ZJ, Huang H, Huang LM, Li YC, Li XB. 2008a. PCR-RFLP analysis of large 474 subunit rDNA of symbiotic dinoflagellates in scleractinian corals from Luhuitou fringing reef of Sanya, Hainan. Biodiversity Science 16: 498-502 (in Chinese with English abstract).

Dong ZJ, Huang H, Huang LM, Li YC, Zhou GW. 2008b. Molecular taxonomy and diversity of symbiotic dinoflagellates in scleractinian corals near the sea off the Dongshan Island in Fujian Province. Journal of Oceanography in Taiwan Strait 27: 135-140 (in Chinese with English abstract).

Dong ZJ, Huang H, Huang LM, Li YC. 2009. Diversity of symbiotic algae of the genus 482 Symbiodinium in scleractinian corals of the Xisha Island in the South China Sea. Journal of Systematics and Evolution 47: 321-326.

Fabricius KE, Mieog JC, Colin PL, Idip D, van Oppen MJH. 2004. Identity and 485 diversity of coral endosymbionts (zooxanthellae) from three Palauan reefs with 
contrasting bleaching, temperature and shading histories. Molecular Ecology 13: 2445-2458.

488

489

490

491

Fang LS, Shao KT, Liu L, Li JJ. 1990. A survey of the marine ecological resources of Dong-Sha Atoll. Fishery Management Department, Kaohsiung City government, Taiwan, 61 pp (in Chinese with English abstract).

Fang LS. 1998. The status of marine ecology in Dong-Sha Atoll. European-Asian workshop on Investigation and Management of Mediterranean and South China Sea Coastal Zone. Nov 9-11 1998 Hong Kong.

Ferrara GB, B Murgia, AM Parodi, L Valisano, C Cerrano, G Palmisano, G Bavestrello, and M Sara. 2006. The assessment of DNA from marine organisms via a modified salting-out protocol. Cellular and Molecular Biology Letters 11:155-160.

Graham NAJ, Wilson SK, Jennings S, Polunin NVC, Bijoux JP, Robinson J. 2006. Dynamic fragility of oceanic coral reef ecosystems. Proceedings of the National Academy of Sciences 103: 8425-8429.

Hoegh-Guldberg O. 1999. Climate change, coral bleaching and the future of the world's coral reefs. Marine and Freshwater Research 50: 839-866.

Hoegh-Guldberg O. 2004. Coral reefs in a century of rapid environmental change. Symbiosis 37: 1-31.

Hoegh-Guldberg O, Mumby PJ, Hooten AJ, Steneck RS, Greenfield P, Gomez E, Harvell CD, Sale PF, Edwards AJ, Caldeira K, Knowlton N, Eakin CM, IglesiasPrieto R, Muthiga N, Bradbury RH, Dubi A, Hatziolos ME. 2007. Coral reefs under rapid climate change and ocean acidification. Science 318:1737-1742.

Huang D, Benzoni F, Fukami, H, Knowlton N, Smith N, Budd A. 2014. Taxonomic classification of the reef coral families Merulinidae, Montastraeidae, and 
510 Diploastraeidae (Cnidaria: Anthozoa: Scleractinia). Zoological Journal of the

511 Linnean Society 171:277-355.

512 Huang H, Dong ZJ, Huang LM, Zhang JB. 2006. Restriction fragment length

513 polymorphism analysis of large subunit rDNA of symbiotic dinoflagellates from

514 scleractinian corals in the Zhubi Coral Reef of the Nansha Islands. Journal of

$515 \quad$ Integrative Plant Biology 48: 148-152.

516 Hughes TP, Baird AH, Bellwood DR, Card M, Connolly SR, Folke C, Grosberg R,

517 Hoegh-Guldberg O, Jackson JBC, Kleypas J, Lough JM, Marshall P, Nystrom M,

518 Palumbi SR, Pandolfi JM, Rosen B, Roughgarden J. 2003. Climate Change, Human

519 Impacts, and the Resilience of Coral Reefs. Science 301:929-933.

520 Hughes TP, Huang H, Young MAL. 2013. The wicked problem of China's disappearing 521 coral reefs. Conservation Biology 27: 261-269.

522 Iglesias-Prieto R, Beltran VH, LaJeunesse TC, Reyes-Bonilla H, Thome PE. 2004.

523 Different algal symbionts explain the vertical distribution of dominant reef corals in 524 the eastern Pacific. Proceedings of the Royal Society B-Biological Sciences $525 \quad 271: 1757-1763$.

526 Jones CG, Lawton JH, Shachak M. 1994. Organisms as Ecosystem Engineers. Oikos 69: $527 \quad 373-386$.

528 Jones AM, Berkelmans R, van Oppen MJH, Mieog JC, Sinclair W. 2008. A community 529 change in the algal endosymbionts of a scleractinian coral following a natural 530 bleaching event: field evidence of acclimatization. Proceedings of the Royal $531 \quad$ Society B-Biological Sciences 275: 1359-1365. 
532 Jones AM, Berkelmans R. 2010. Potential costs of acclimatization to a warmer climate:

533 growth of a reef coral with heat tolerant vs. sensitive symbiont types. PLoS ONE 5:

$534 \quad$ e10437.

535 Keshavmurthy S, Meng P-J, Wang J-T, Kuo C-Y, Yang S-Y, Hsu C-M, Gan C-H, Dai

536 C-F, Chen CA. 2014. Can resistant coral-Symbiodinium associations enable coral

537 communities to survive climate change? A study of a site exposed to long-term hot

$538 \quad$ water input. PeerJ 2:e327; DOI 10.7717/peerj.327.

539 LaJeunesse TC, Trench RK. 2000. The biogeography of two species of Symbiodinium

540 (Freudenthal) inhabiting the intertidal anemone, Anthopleura elegantissima

541 (Brandt). Biological Bulletin 199: 126-134.

542 LaJeunesse TC. 2001. Investigating the biodiversity, ecology, and phylogeny of

543 endosymbiotic dinoflagellates in the genus Symbiodinium using the internal

544 transcribed spacer region: in search of a "species" level marker. J Phycol 37: 866-

$545 \quad 880$

546 LaJeunesse TC. 2002. Diversity and community structure of symbiotic dinoflagellates

547 from Caribbean coral reefs. Marine Biology 141: 387-400.

548 LaJeunesse TC, Smith R, Walther M, Pinson J, Pettay DT, McGinley M, Aschaffenburg

549 M, Medina-Rosas P, Cupul-Magna AL, Perez AL, Reyes-Bonilla H, Warner M.

550 2010a. Host-symbiont recombination versus natural selection in the response of

551 coral-dinoflagellate symbioses to environmental disturbance. Proceedings of the

552 Royal Society B-Biological Sciences 277: 2925-2934.

553 Lajeunesse TC, Pettay DT, Sampayo EE, Phongsuwan N, Brown BE, Obura DO,

554 Hoegh-Guldberg O, Fitt WK. 2010b. Long-standing environmental conditions, 
geographic isolation and host-symbiont specificity influence the relative ecological dominance and genetic diversification of coral endosymbionts in the genus Symbiodinium. Journal of Biogeography 37:785-800

Li JJ, Lee TF, Tew KS, Fang LS. 2000. Changes in the Coral Community at Dong-Sha Atoll, South China Sea from 1975 to 1998. Acta Zoologica Taiwanica 11 (1): 1-15.

Li JJ, Fang LS. 2002. The management of Dong-Sha Atoll as an effective marine 561 protected area. Proceedings of the fourth Conference on the Protected Areas of East Asia (IUCN/WCPA/EA-4) p 403-415 Taipei.

Little AF, van Oppen MJH, Willis BL. 2004. Flexibility in algal endosymbioses shapes growth in reef corals. Science 304:1492-1494.

Loh WKW, Loi T, Carter D and Hoegh-Guldberg O. 2001. Genetic variability of the symbiotic dinoflagellates from the wide ranging coral species Seriatopora hystrix and Acropora longicyathus in the Indo-West Pacific. Marine Ecology Progress

Ma TYH. 1937. On the growth of reef corals and its relation to the sea water temperature. Mem Nat Inst Acad Sinica Zool 1: 1-226.

McManus J. 2010. Towards establishing a Spartly Islands international marine peace park: Ecological importance and supportive collaborative activities with an emphasis on the role of Taiwan. Ocean Development \& International Law 41: 270280.

Mieog JC, van Oppen MJH, Cantin NE, Stam WT, Olson JL. 2007. Real-time PCR 576 reveals a high incidence of Symbiodinium clade D at low levels in four 
577 scleractinian corals across the Great Barrier Reef: implications for symbiont $578 \quad$ shuffling. Coral Reefs 26: 449-457.

579 Moberg F, Folke C. 1999. Ecological goods and services of coral reef ecosystems. $580 \quad$ Ecological Economics 29: 215-233.

581 Pochon X, Pawloski J, Zaninetti L and Rowan R. 2001. High genetic diversity and 582 relative specificity among Symbiodinium -like endosymbiotic dinoflagellates in 583 soritid foraminiferans. Marine Biology 139: 1067-1078.

584 Pochon X, Montoya-Burgos JI, Stadelmann B, Pawloski J. 2006. Molecular phylogeny, 585 evolutionary rates, and divergence timing of the symbiotic dinoflagellates genus $586 \quad$ Symbiodinium. Phylogenetics and Evolution 38: 20-30.

587 Pochon X, Gates RD. 2010. A new Symbiodinium clade (Dinophyceae) from soritid 588 foraminifera in Hawaii. Molecular Phylogenetics and Evolution 56: 492-497.

Rowan R, Powers DA. 1991a. A molecular genetic classification of zooxanthellae and the evolution of animal-algal symbioses. Science 51: 1348-1351.

591 Rowan R, Powers DA. 1991b. Molecular genetic identification of symbiotic dinoflagellates 592 (zooxanthellae). Marine Ecology Progress Series 71: 65-73.

593 Rowan R. 2004. Thermal adaptation in reef coral symbionts. Nature 430:742.

594 Sampayo EM, Ridgeway T, Bongaerts P, Hoegh-Guldberg O. 2008. Bleaching 595 susceptibilityand mortality of corals are determined by fine-scale differences in symbiont type. Proceedings of National Academy of Sciences 105:10444-10449.

597 Silverstein RN, Correa A, Lajeunesse TC, Baker AC. 2011. Novel algal symbiont 598 (Symbiodinium spp.) diversity in reef corals of Western Australia. Marine Ecology 599 Progress Series 422: 63-75 
600 Stat M, Loh W, Hoegh-Guldberg O, Carter DA. 2009. Stability of coral-endosymbiont 601 associations during and after a thermal stress event in the southern Great Barrier $602 \quad$ Reef. Coral Reefs 28: 709-713.

603 Soong K, Dai CF, Lee CP. 2002. Status of Pratas Atoll in South China Sea. Proceedings 604 of the $4^{\text {th }}$ Conference on the Protected Areas of East Asia (IUCN/WCPA/EA-4) p 605 739-742 Taipei.

606 Thornhill D, LaJeunesse TC, Kemp DW, Fitt WK, Schmidt GW. 2006. Multi-year, 607 seasonal genotypic surveys of coral-algal symbioses reveal prevalent stability or 608 post-bleaching reversion. Marine Biology 148: 711-722.

609 van Oppen MJH, Palstra FP, Piqet AMT, Miller DJ. 2001. Patterns of oral610 dinoflagellate associations in Acropora: Significance of local availability and 611 physiology of Symbiodinium strains and host-symbiont selectivity. Proceedings of 612 the Royal Society - Biological Sciences 268: 1759-1767.

613 van Oppen MJH, Mahiny A, Done T. 2005. Geographic distribution of zooxanthellae 614 types in three coral species on the Great Barrier Reef sampled after the 2002 615 bleaching event. Coral Reefs 24: 482-487.

616 Veron JEN, Stafford-Smith M. 2000. Corals of the World. Australian Institute of 617 Marine Science, Townsville.

618 Warner ME, LaJeunesse TC, Robison JD, Thur RM. 2006. The ecological distribution 619 and comparative photobiology of symbiotic dinoflagellates from reef corals in 620 Belize: potential implications for coral bleaching. Limnology and Oceanography $621 \quad 51: 1887-1897$. 
622 Weber M, Medina M. 2012. The role of microalgal symbionts (Symbiodinium) in 623 holobiont physiology. Advances in Botanical Research 64: 119-140.

624 Weis VM. 2008. Cellular mechanisms of Cnidarian bleaching: stress causes the collapse of 625 symbiosis. The Journal of Experimental Biology 211:3059-3066.

626 Wilkinson C. 2004. Status of coral reefs of the world. Australian Institute of Marine 627 Science, Townsville, Australia.

628 Yang RT, Huang CC, Lee CS, Tsai HJ, Sun CL. 1975. Report on a survey at Dongsha 629 Island and the adjacent area. Special Publication No. 8, Institute of Oceanography, $630 \quad$ National Taiwan University, Taipei, 15 p. 
Figure 1

Figure of sampling location

Figure 1. Map of Dongsha Atoll in the South China Sea. Sampling sites in the lagoon are marked 2 - 10.

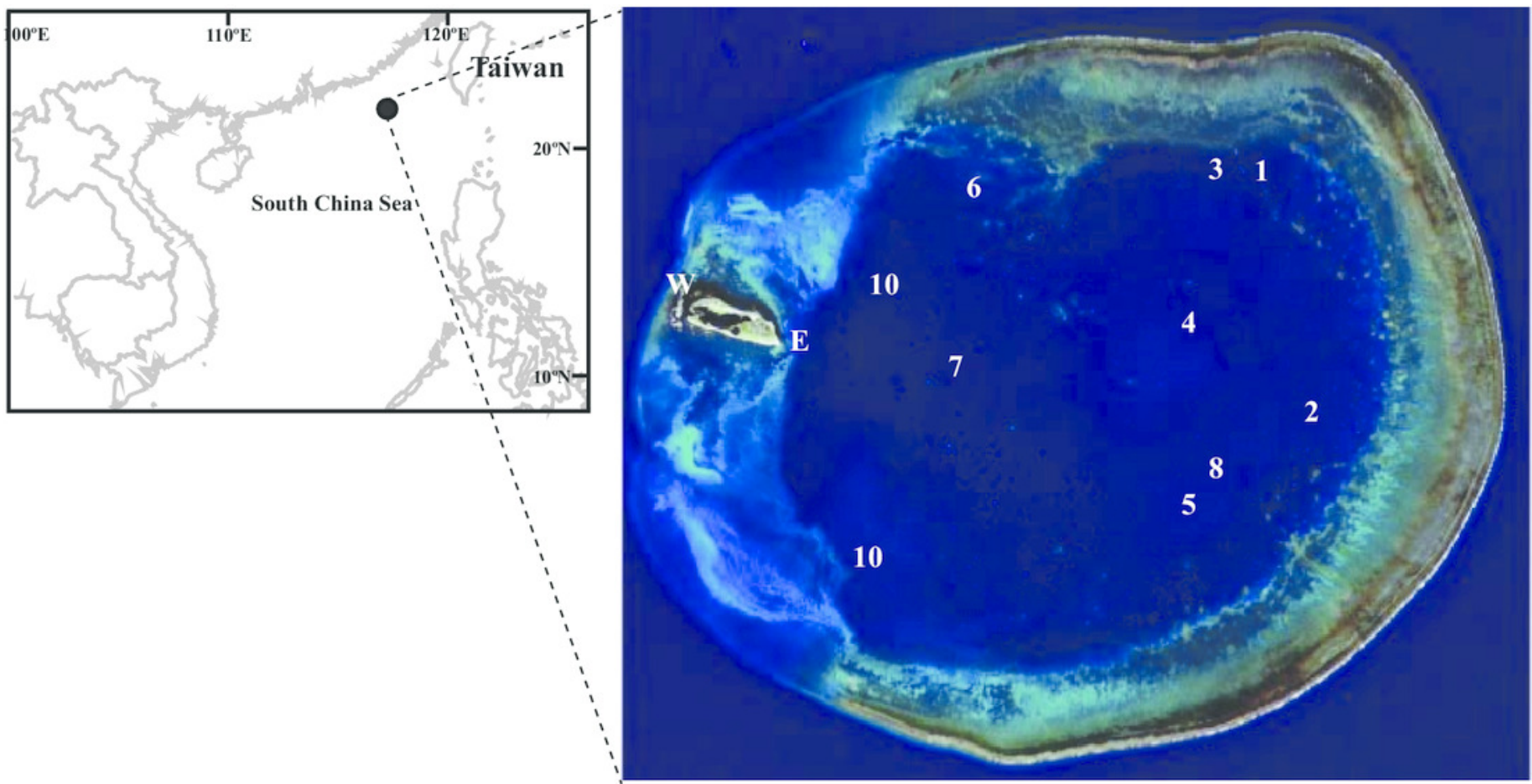


Figure 2

Seawater temperature at the study site in 2009 and 2010

Figure 2. Seawater temperature in 2009: June to September (A); and 2010: May to September (B). The red line represents Reef Top and the blue line represents Reef Base. Heat map of seawater temperatures measured at reef base and reef top during JuneSeptember and May-September in 2009 (A) and 2010 (B), respectively. The y-axis values are seawater temperature recorded at 30 minutes intervals.
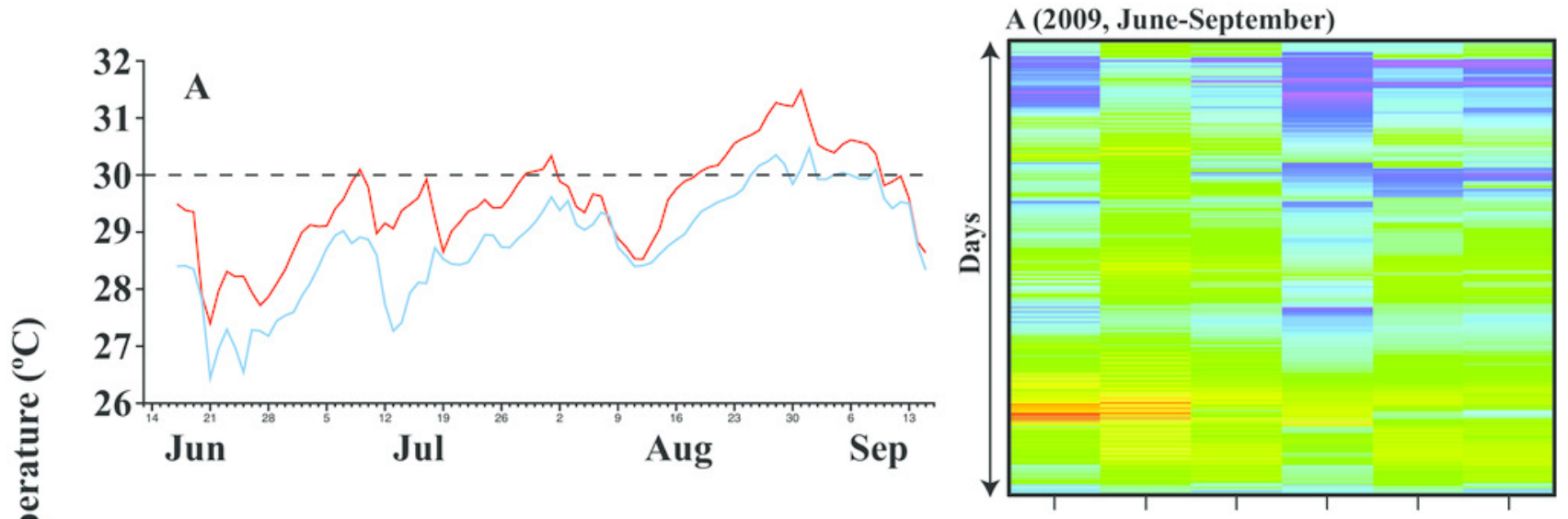

${ }^{\circ} \mathrm{C}$
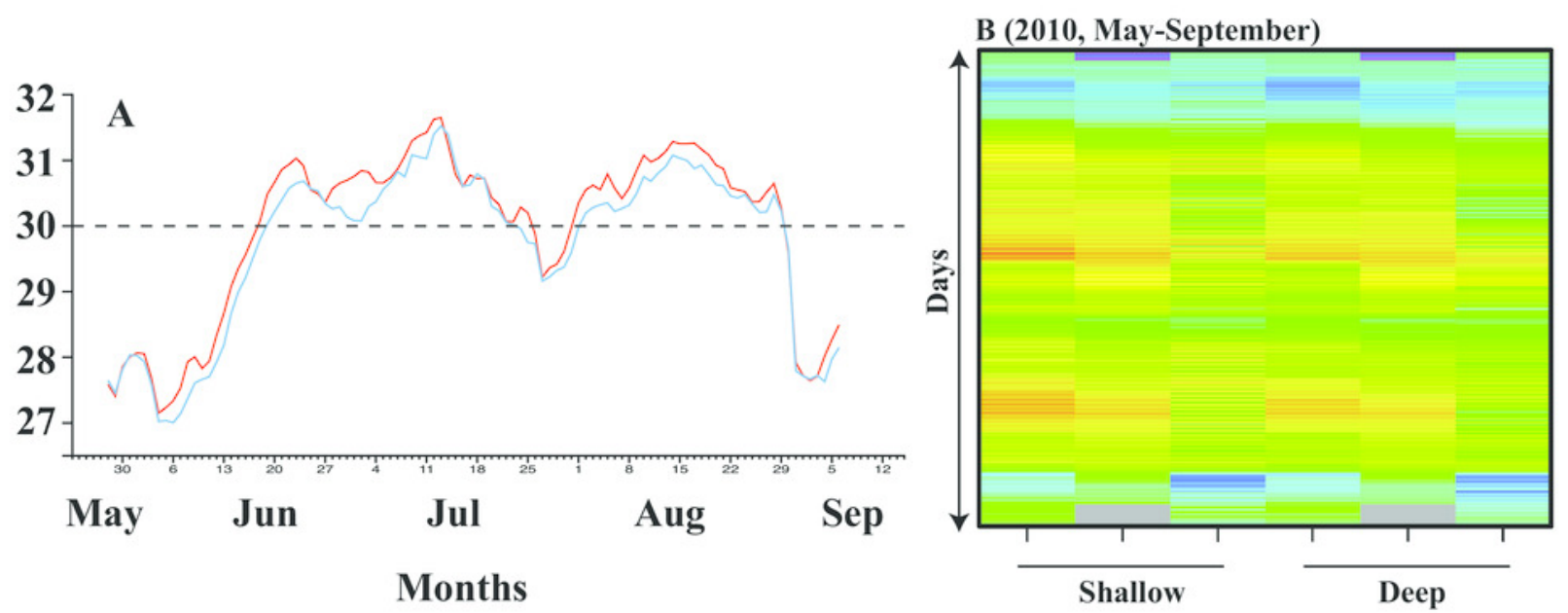

-33.01

$-30.75$

28.49

Months

Deep 


\section{Figure 3}

Symbiodinium clade distribution corals genera in 2009 and 2010

Figure 3. Symbiodinium clade distribution (in percentages) in corals sampled in 2009 (20 genera) and 2010 (12 genera) in Dongha Atoll lagoon. The size of the pie-charts are proportional to the coral sample number. Cream=Symbiodinium C; Black=Symbiodnium D; and Yellow=Symbiodinium D. Sample numbers are indicated in brackets next to each genus name. Numbers inside the pie-charts indicate the percentage of clades 


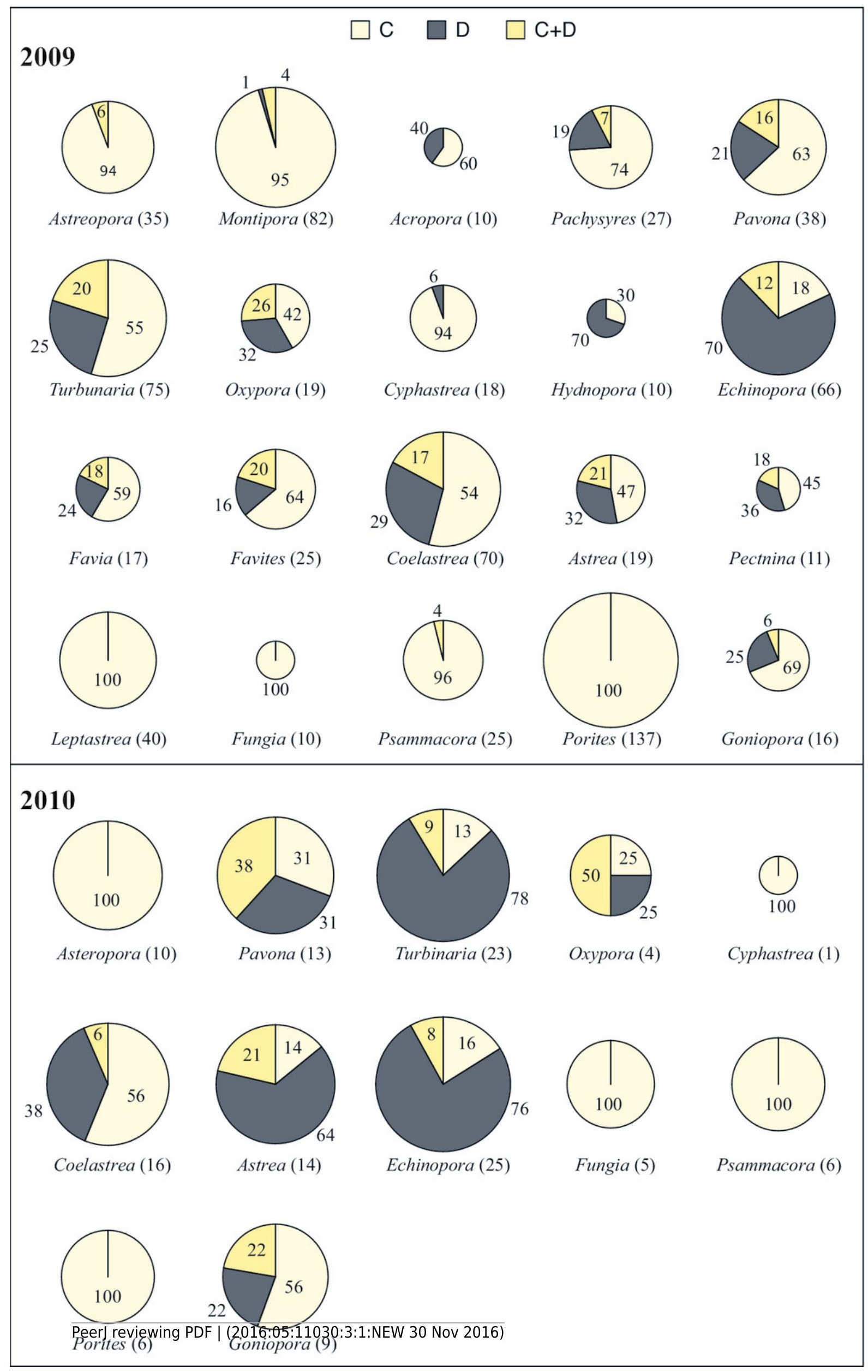


Figure 4

Symbiodinium clade distribution in corals at shallow and deep waters in 2009 and 2010

Figure 4. Symbiodinium clade distribution in corals at shallow and deep waters in 2009 (20 genera) and 2010 (12 genera) in Dongha Atoll lagoon. The size of the pie-charts are proportional to the coral sample number. Cream=Symbiodinium C; Black=Symbiodnium D; and Yellow=Symbiodinium D. Numbers inside the pie-charts indicate the percentage of clades 


$$
\mathrm{C} \square \mathrm{D} \square \mathrm{C}+\mathrm{D}
$$

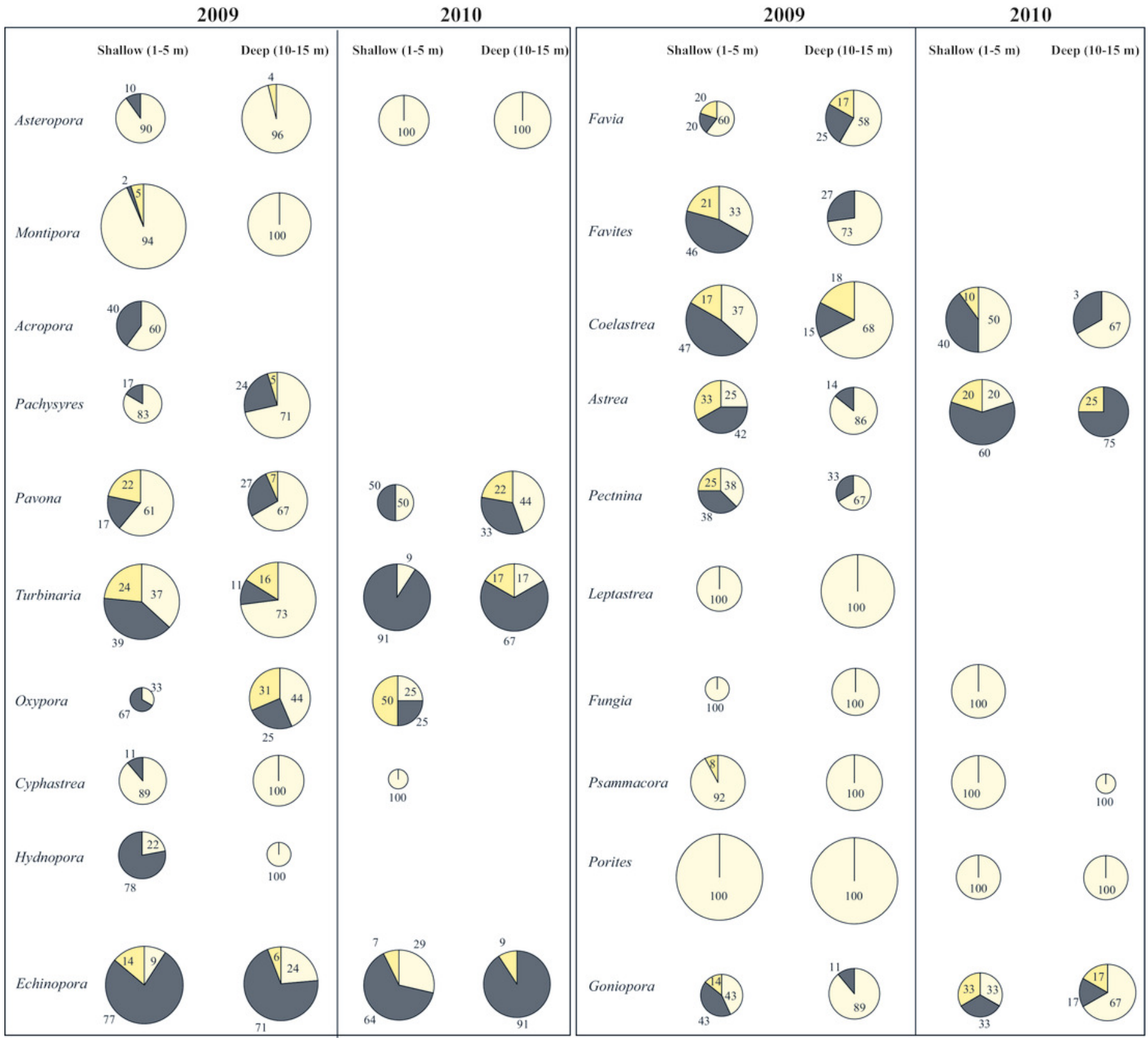




\section{Table $\mathbf{1}$ (on next page)}

Table 1

Table 1. Percentage of daily average seawater temperature over $30^{\circ} \mathrm{C}$ recorded during the sampling period in 2009 and 2010 within each location 
1 Table 1. Percentage of daily average seawater temperature over $30^{\circ} \mathrm{C}$ recorded during the 2 sampling period in 2009 and 2010 within each location

\begin{tabular}{|c|c|c|}
\hline Temperature over $30^{\circ} \mathrm{C}$ & 2009 & 2010 \\
\hline Reef 1 Top & & $68.10 \%$ \\
\hline Reef 1 Base & $7.30 \%$ & $62.30 \%$ \\
\hline Reef 2 Base & $3.20 \%$ & \\
\hline Reef 4 Top & & $65.50 \%$ \\
\hline Reef 4 Base & & $64.30 \%$ \\
\hline Reef 5 Top & $23.90 \%$ & \\
\hline Reef 5 Base & $10.40 \%$ & \\
\hline Reef 6 Top & $52.70 \%$ & \\
\hline Reef 6 Base & $19.40 \%$ & \\
\hline Reef 9 Top & $31.20 \%$ & $48.80 \%$ \\
\hline Reef 9 Base & $23.60 \%$ & $39.80 \%$ \\
\hline Reef Top over $30^{\circ} \mathrm{C}$ & $35.90 \%$ & $60.80 \%$ \\
\hline Reef Base over $30^{\circ} \mathrm{C}$ & $12.80 \%$ & $55.50 \%$ \\
\hline
\end{tabular}

3

4 


\section{Table 2 (on next page)}

Table 2

Table 2. ITS2 DGGE Symbiodinium types in 2009 and 2010 
2 Table 2. ITS2 DGGE Symbiodinium types in 2009 and 2010

\begin{tabular}{|c|c|c|c|c|c|c|}
\hline \multicolumn{4}{|c|}{2009} & \multicolumn{3}{|c|}{2010} \\
\hline Genus & Depth & $\begin{array}{l}\text { Sample } \\
\text { Number }\end{array}$ & DGGE & Depth & $\begin{array}{l}\text { Sample } \\
\text { Number }\end{array}$ & DGGE \\
\hline \multirow[t]{2}{*}{ Asteropora } & 3 top & 1 & $\mathrm{C} 1$ & 3 top & 1 & $\mathrm{C} 1$ \\
\hline & 2 base & 1 & $\mathrm{C} 1$ & 3 base & 2 & $\mathrm{C} 1$ \\
\hline \multirow[t]{9}{*}{ Montipora } & 2 top & 3 & C15, D1 & & & \\
\hline & 2 base & 1 & $\mathrm{C} 15$ & & & \\
\hline & 3 top & 3 & $\mathrm{C} 3, \mathrm{C} 15$ & & & \\
\hline & 3 base & 1 & $\mathrm{C} 15$ & & & \\
\hline & 4 top & 2 & $\mathrm{C} 15$ & & & \\
\hline & 7 top & 1 & $\mathrm{C} 15$ & & & \\
\hline & 8 top & 1 & $\mathrm{C} 15$ & & & \\
\hline & 10 top & 1 & $\mathrm{C} 15$ & & & \\
\hline & 10 base & 5 & $\mathrm{C} 15, \mathrm{C} 30$ & & & \\
\hline Acropora & 6 top & 4 & $\begin{array}{l}\text { C1, C3, D1, } \\
\text { D1a }\end{array}$ & & & \\
\hline \multirow[t]{6}{*}{ Pavona } & 2 top & 1 & $\mathrm{C} 1, \mathrm{C} 1 \mathrm{~b}, \mathbf{D} 1$ & 3 top & 2 & C1b, D1, D1a \\
\hline & 3 top & 5 & $\begin{array}{l}\text { C1b+D1, D1a, } \\
\mathrm{C} 1\end{array}$ & 3 base & 1 & $\mathrm{C} 1+\mathrm{C} 1 \mathrm{~b}$ \\
\hline & 3 base & 2 & $\mathrm{C} 1 \mathrm{~b}$ & 6 base & 5 & $\mathrm{C} 1, \mathrm{C} 1 \mathrm{~b}, \mathrm{C} 27, \mathrm{D} 1, \mathrm{D} 1 \mathrm{a}$ \\
\hline & 4 top & 3 & $\mathrm{C} 1, \mathrm{C} 1 \mathrm{~b}, \mathbf{D} 1 \mathbf{a}$ & & & \\
\hline & 7 base & 1 & $\mathrm{C} 1+\mathrm{C} 1 \mathrm{~b}$ & & & \\
\hline & 10 base & 1 & $\mathrm{C} 1 \mathrm{~b}$ & & & \\
\hline \multirow[t]{4}{*}{ Turbinaria } & 2 base & 1 & $\mathrm{C} 21 \mathrm{a}$ & 3 top & 1 & D1+D1a \\
\hline & 4 base & 1 & $\mathrm{C} 40$ & 3 base & 3 & D1+D1a \\
\hline & 5 base & 1 & $\mathrm{C} 1$ & 6 base & 5 & $\mathrm{C} 15, \mathbf{D 1}+\mathbf{D} 1 \mathbf{a}$ \\
\hline & 6 base & 1 & $\mathrm{C} 40$ & 10 top & 4 & C21a, D1+D1a \\
\hline \multirow[t]{2}{*}{ Oxypora } & 2 base & 1 & $\mathrm{C} 27$ & 6 top & 4 & C27, C15, D1+D1a \\
\hline & 10 base & 4 & D1, D1a, C1 & & & \\
\hline \multirow[t]{6}{*}{ Echinopora } & 2 top & 2 & D1 & 3 top & 1 & D1 \\
\hline & 3 top & 4 & D1, C40, D1a & 3 base & 2 & C27, D1, D1a \\
\hline & 3 base & 1 & D1a & 6 top & 4 & C40, D1, D1a \\
\hline & 4 top & 1 & C40+D1a & 6 base & 1 & D1 \\
\hline & 5 base & 1 & D1a & 10 top & 1 & D1 \\
\hline & 10 base & 2 & C40, D1a & & & \\
\hline \multirow[t]{2}{*}{ Favites } & 2 top & 2 & D1 & & & \\
\hline & 3 top & 2 & D1, D1a & & & \\
\hline \multirow[t]{4}{*}{ Astrea } & 2 top & 1 & D1 & 3 top & 3 & D1+D1a \\
\hline & 6 top & 2 & D1a & 3 base & 3 & D1+D1a \\
\hline & 8 top & 2 & C3, D1a & 6 top & 2 & D1+D1a \\
\hline & & & & 10 top & 1 & D1 \\
\hline \multirow[t]{2}{*}{ Leptastrea } & 6 base & 1 & $\mathrm{C} 1$ & 3 top & 1 & $\mathrm{C} 27$ \\
\hline & 10 base & 1 & $\mathrm{C} 1$ & & & \\
\hline \multirow[t]{4}{*}{ Fungia } & 2 top & 1 & $\mathrm{C} 1+\mathrm{C} 27$ & 10 top & 3 & $\mathrm{C} 27$ \\
\hline & 2 base & 1 & $\mathrm{C} 27$ & & & \\
\hline & 10 top & 1 & $\mathrm{C} 1$ & & & \\
\hline & 10 base & 1 & $\mathrm{C} 27$ & & & \\
\hline \multirow[t]{2}{*}{ Psammacora } & 2 top & 2 & $\mathrm{C} 1, \mathrm{C} 27$ & 3 base & 1 & $\mathrm{C} 1$ \\
\hline & 10 base & 1 & $\mathrm{C} 1$ & 6 top & 2 & $\mathrm{C} 27$ \\
\hline \multirow[t]{2}{*}{ Porites } & 2 base & 2 & $\mathrm{C} 15$ & 3 top & 3 & $\mathrm{C} 15$ \\
\hline & 3 top & 2 & C15 & 3 base & 2 & $\mathrm{C} 15$ \\
\hline
\end{tabular}




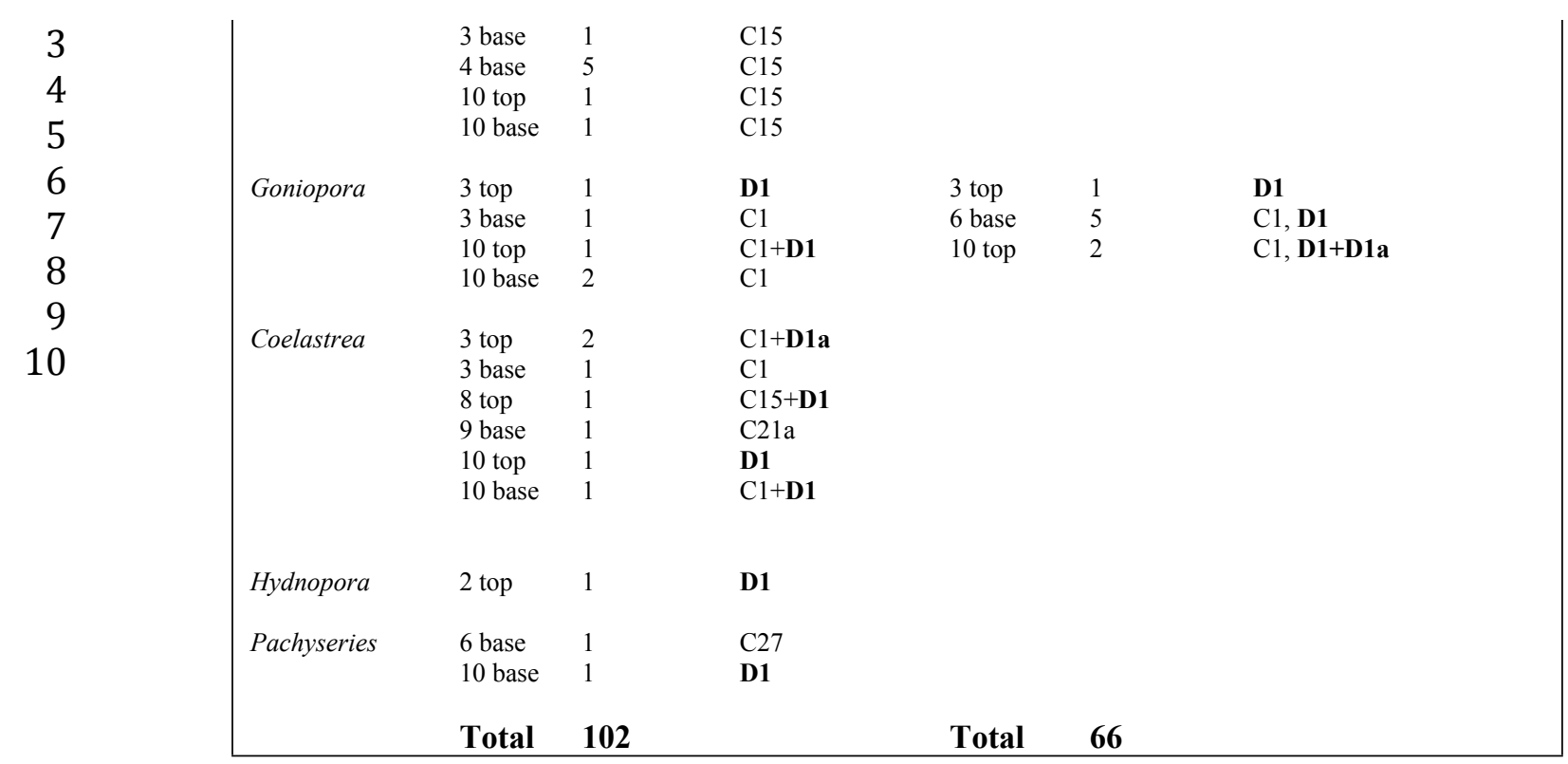


11

12

13

PeerJ reviewing PDF | (2016:05:11030:3:1:NEW 30 Nov 2016) 


\section{Table 3(on next page)}

Table 3

Table 3. Published reports of Symbiodinium clades diversity of scleractinian corals in genus in the West Pacific and South China Sea. 
1 Table 3. Published reports of Symbiodinium clades diversity of scleractinian corals in genus in the West Pacific and South China Sea.

\begin{tabular}{|c|c|c|c|c|c|c|c|c|}
\hline Location & $\begin{array}{c}\text { No. of } \\
\text { Genera } \\
\text { analyzed }\end{array}$ & clade A & clade $B$ & clade $\mathrm{C}$ & clade D & clade $\mathbf{F}$ & multiple clades & Reference \\
\hline Penghu Island and Kenting, Taiwan & 26 & 0 & 0 & 26 & 2 & & 6 & Chen et al., 2005a \\
\hline Dongshan Island, China & 3 & 0 & 0 & 3 & $\mathbf{0}$ & & 0 & Dong et al., 2008a \\
\hline Luhuitou fringing reef, China & 11 & 0 & 0 & 11 & 2 & & 2 & Dong et al., 2008b \\
\hline Xisha Island, China & 25 & 0 & 0 & 25 & 3 & & 3 & Dong et al., 2009 \\
\hline Zhubi coral reef of the Nansha Islands, China & 4 & 0 & 0 & 4 & 1 & & 1 & Huang et al., 2006 \\
\hline Kenting, Taiwan & 16 & & & 16 & 13 & & 13 & Keshavmurthy et al., 2014 \\
\hline Dong-Sha Atoll, Taiwan & 20 & 0 & 0 & 20 & 15 & & 14 & Present study \\
\hline Total occurrences of clades & 106 & 1 & $\mathbf{0}$ & 106 & 36 & 1 & 39 & \\
\hline
\end{tabular}


